\title{
PENGARUH KOMUNIKASI INTERPERSONAL TERHADAP KINERJA PENYULUH KELUARGA BERENCANA (PKB) DI BKKBN PROPINSI SULAWESI TENGGARA
}

\author{
Faidha1 \\ 1Widyaiswara Perwakilan BKKBN Sulawesi Tenggara \\ Email: drsfaidha@gmail.com
}

\begin{abstract}
Abstrak. Fenomena yang terjadi program yang dicanangkan oleh BKKBN Propinsi Sulawesi Tenggara berhadapat dengan beberapa masalah prinsipil, yaitu; adanya paradigma leluhur yang masih beranggapan bahwa banyak anak banyak rejeki, pendapat umum bahwa program Keluarga berencana bertentangan dengan nilai agama yang mereka percayai. Penelitian ini bermaksud mengkaji pengaruh komunikasi interpersonal yang dilakukan oleh kader Keluarga Berencana di Wilayah Sulawesi Tenggara. Penelitian dilakukan melalui pendekatan kuantitatif, dimana sampel dipilih menurut kebutuhan sebanyak 40 orang. Instrumen penelitian menggunakan kuesioner. Selanjutnya penelitian menggunakan uji validitas (test of validity) dan uji reliabilitas (test of realiability). Data kemudian diolah menggunakan Uji Validitas dan Uji Reabilitas, Dengan menguji pengaruh komunikasi interpersonal terhadap kinerja pegawai penyuluh. Hasil penelitian menunjukkan bahwa hubungan komunikasi interpersonal yang terdiri dari keterbukaan, empati, dukungan dan rasa positif ditingkatkan maka meningkatkan kinerja penyuluh. Sebaliknya, apabila terjadi komunikasi yang buruk akibat tidak terjalinnya hubungan yang baik, sehingga akan berdampak pada hasil kinerja yang tidak maksimal.
\end{abstract}

\section{Kata Kunci: Komunikasi Interpersonal, Kinerja, Sulawesi Tenggara}

Abstract: The phenomenon that occurs in the program launched by the BKKBN of Southeast Sulawesi Province is faced with several principal issues, namely; the paradigm of ancestors who still think that many children have a lot of luck, the general opinion that the family planning program is contrary to the religious values they believe. This study intends to examine the effect of interpersonal communication carried out by family planning cadres in the Southeast Sulawesi region. The study was conducted through a quantitative approach, in which samples were selected according to the needs of 40 people. The research instrument used a questionnaire. Furthermore, the study uses a test of validity (test of validity) and a test of reliability (test of reliability). The data is then processed using the Validity Test and Reliability Test, by testing the effect of interpersonal communication on the performance of extension workers. The results showed that interpersonal communication relationships consisting of openness, empathy, support and a positive sense were improved, thus increasing the performance of instructors. Conversely, if there is bad communication due to not establishing a good relationship, so it will have an impact on the results of performance that is not optimal.

Keywords: Interpersonal Communication, Performing, South East Sulawesi 


\section{Pendahuluan}

Karakteristik kehidupan sosial mewajibkan setiap individu untuk membangun sebuah relasi dengan yang lain, sehingga akan terjalin sebuah ikatan perasaan yang bersifat timbal balik dalam suatu pola hubungan yang dinamakan hubungan interpersonal.

Komunikasi interpersonal yang diungkapkan oleh Agus M. Hardjana dan Deddy Mulyana: Hardjana (2003) menyatakan bahwa, "Komunikasi interpersonal adalah interaksi tatap muka antar dua atau beberapa orang, dimana pengirim dapat menyampaikan pesan secara langsung dan penerima pesan dapat menerima dan menanggapi secara langsung pula." Begitupun Mulyana (2010) menyatakan bahwa, "Komunikasi interpersonal atau komunikasi antar pribadi adalah komunikasi antara orang-orang secara tatap muka, yang memungkinkan setiap pesertanya menangkap reaksi orang lain secara langsung, baik secara verbal maupun non verbal.

Hal yang sama juga diperkuat oleh pernyataan Devito (dalam Effendy, 2003) menyatakan bahwa, "Komunikasi interpersonal adalah penyampaian pesan oleh satu orang dan penerimaan pesan oleh orang lain atau sekelompok kecil orang, dengan berbagai dampaknya dan dengan peluang untuk memberikan umpan balik segera". Kemudian, faktor pembentuk variabel komunikasi interpersonal dalam penelitian terdiri dari lima indikator variabel yaitu: 1) keterbukaan (openess,) 2) Empati (emphaty) 3) Dukungan (supportiveness) 4) rasa positif (positiveness) dan 5) kesetaraan (equality) di adopsi dari teori Agus M. Hardjana dan Deddy Mulyana: Hardjana (2003), Mulyana (2010) Muhammad (2005) Efendi (2006), Sopiah (2008), Baharum et al (2005). Selanjutnya penelitian ini berusaha mengartikulasi, menguji dan menganalisis komunikasi interpersonal yang dilakukan oleh Festus Femin (2014), Wawan Ridwan, Soewarto Hardhienata dan M. Entang (2016) dan Saftian Pradana, I Wayan Bagia dan Gede Putu Agus Jana Susila (2016), Abdul Ghofar et al (2018), Saraih U. N. et al (2019), Nana Herdiana Abdurrahman (2018) dan Syifa Aulia Gumay et al (2018) dengan hasil penelitian menunjukkan bahwa komunikasi interpersonal berpengaruh signifikan terhadap kinerja.

Kemudian, lebih lanjut Robbins (2008) mendefenisikan kinerja yaitu suatu hasil yang dicapai oleh pegawai dalam pekerjaannya menurut kriteria tertentu yang berlaku untuk suatu pekerjaan. Kinerja adalah tingkatan pencapaian hasil atas 
pelaksanaan tugas tertentu. Simanjutak (2005). Mathis dan Jackson (2011) Kinerja (Perfomance Appraisal-PA) adalah proses evaluasi seberapa baik karyawan mengerjakan pekerjaan dibandingkan dengan satu set standar, dan kemudian mengkomunikasikannya dengan para karyawan.

Kinerja adalah kemampuan pegawai menyelesaikan kewajibannya sesuai dengan waktu dan rencana atau sesuai dengan yang diharapkan. Pengukuran kinerja karyawan dapat dilakukan terhadap kinerja yang nyata dan terukur Abdullah, (2014). Faktor pembentuk variabel kinerja pegawai dalam penelitian ini yang dikemukakan oleh Sutrisno, (2010) yang terdiri dari 1) kuantitas kerja, 2) kualitas kerja, 3) ketangguhan, 4) kerja sama dan 5) ketepatan waktu. Komunikasi dinilai sebagai aspek yang penting ketika melakukan penyuluhan, komunikasi adalah proses penyampaian pesan yang dilakukan oleh komunikator kepada komunikan. Orang yang memberi pesan (komunikator) dalam hal ini adalah Penyuluh Keluarga Berencana (PKB) dan yang menerima pesan (komunikan) adalah masyarakat.

Komunikasi antar pribadi dalam bentuk penyuluhan biasa digunakan para aparatur Badan Kependudukan dan Keluarga
Berencana Nasional (BKKBN) dalam memperkenalkan program yang dicanangkan yakni menekanan tingkat kelahiran. Fenomena yang terjadi program yang dicanangkan oleh BKKBN Propinsi Sulawesi Tenggara tersebut bukanlah hal yang mudah mengingat masih kentalnya paradigma leluhur yang masih tertanam dimasyarakat diantaranya mereka masih banyak yang beranggapan bahwa banyak anak banyak rejeki. Selain paradigma tersebut, adapula beberapa sekelompok masyarakat beranggapan bahwa program Keluarga Berencana tersebut bertentangan dengan nilai agama yang mereka percayai. Selain itu, kegiatan penyuluh lapangan untuk memberikan pemahaman tentang pentingnya keluarga berencana kepada berbagai pemangku kepentingan juga belum menghasilkan komitmen yang kuat untuk mendukung penyelenggaraan keluarga berencana. Kemudian, kegiatan komunikasi, informasi dan edukasi (KIE) yang dilakukan kepada masyarakat belum mampu mengubah nilai tentang jumlah anak ideal yang diinginkan maupun perilaku masyarakat dalam mendapatkan pelayanan kontrasepsi sesuai kebutuhan. Banyak hal yang menyebabkan pencapaian program KB belum sesuai harapan. 
Salah satunya adalah berkurangnya jumlah petugas lapangan keluarga berencana sehingga menyebabkan pembinaan kesertaan ber-KB menjadi terbatas, jangkauan pelayanan KB tidak merata, dan belum optimalnya kualitas Pelayanan KB. Disamping cara penyuluh melakukan komunikasi tentunya pesan yang disampaikan kepada masyarakat oleh Penyuluh Keluarga Berencana harus memiliki muatan pesan yang baik dan tentunya bersifat persuasif. Penelitian ini bermaksud mengkaji pengaruh komunikasi interpersonal yang dilakukan oleh kader Keluarga Berencana di Wilayah Sulawesi Tenggara, dengan tujuan untuk memberikan penilaian komprehensif terkait kaitan antara komunikasi dan kinerja yang dapat ditunjukkan oleh kader.

\section{Metode Penelitian}

Penelitian ini dirancang dengan maksud untuk memberikan penjelasan hubungan kausal antar variabel melalui pengujian hipotesis, dengan demikian maka pendekatan penelitian ini adalah metode deskriptif dalam bentuk explanation dengan menggunakan pendekatan kuantitatif. Sampel ditentukan dengan menggunakan teknik pengambilan sampel Non-probability Sampling melalui pendekatan Purposive
Sampling. Sampel kemudian dipilih melalui kriteria yang berdasarkan pertimbangan (judgement) tertentu atau quota. Dengan begitu, penelitian ini menentukan quota jumlah sampel adalah 40 orang Penyuluh Keluarga Berencana (PKB) BKKBN pada wilayah kerja Sulawesi Tenggara.

Data dikumpulkan dengan dua cara yakni Kuesioner dan Wawancara kepada sampel yang telah ditentukan. Data kemudian dioleh melalui mekanisme pengukuran menggunakan 5 point Likert Scale. Karena itu, untuk menguji kuesioner sebagai instrumen penelitian maka digunakan uji validitas (test of validitu) dan uji reliabilitas (test of realiability). Selajutnya data akan diolah menggunakan Uji Validitas dan Uji Reabilitas, Dengan menguji pengaruh komunikasi interpersonal terhadap kinerja pegawai penyuluh BKKBN di Sulawesi Tenggara. Adapun model persamaan yang akan diestimasi dengan menggunakan analisis regresi sederhana:

\section{Variate value $(Y)=W_{1} X_{1}+W_{n} X_{n}$ (Hair et al., 2010)}

di mana: Variate value $=$ nilai variasi perubahan variable bebas (dependent); X1$\mathrm{X}_{\mathrm{n}}=$ Variasi variabel tertimbang (weight); $\mathrm{X}_{\mathrm{n}}$ adalah variabel yang diamati dan $\mathrm{W}_{\mathrm{n}}$ 
adalah Weight determined yang ditentukan dengan teknik multivariat. Selanjutnya model persamaan yang dapat dinyatakan secara matematis tersebut ditransformasi atau dioperasionalkan dalam penelitian ini sebagai berikut:

$$
K P=W_{1} M K
$$

Dimana:

$$
\begin{aligned}
& \text { KP = Kinerja Penyuluh } \\
& \text { KI }=\text { Komunikasi Interpersonal } \\
& \mathrm{W}_{1}, \mathrm{~W}_{2} \& \mathrm{~W}_{3} \quad=\text { Weight determined atau } \\
& \text { Regression weight } \\
& \text { (standardized beta) }
\end{aligned}
$$

Setelah model penelitian diestimasi maka akan diperoleh nilai dan besaran dari masing-masing parameter dalam model persamaan diatas. Nilai dari parameter positif atau negatif selanjutnya akan digunakan untuk menguji hipotesis penelitian.

\section{Pembahasan}

\section{Profil Kinerja Penyuluh Keluarga Berencana Sulawesi Tenggara}

Program Keluarga Berencana Nasional di Sulawesi Tenggara secara resmi dimulai pada Pelita III (1979/1980) sesuai dengan Keutusan presiden No. 38 tahun 1978 dan surat keputusan kepala BKKBN Nomor : 26/SK-1/1979 bersama 11 Provinsi lainnya di Indonesia yang lazim disebut dengan Provinsi Luar Jawa-Bali II (LJB-II). Pada tahun 1980 dibentuk kelembagaan BKKBN Provinsi dan tahun 1981 di semua Kabupaten dibentuk Satuan Tugas KB yang diketuai oleh Kepala Bagian Kesra Tk. II dan pada tahun 1982/1983 secara bersamaan dibentuk BKKBN Kabupaten dan Koordinator Petugas Lapangan Keluarga Berencana. Pada tahun 1983/1984 nama Koordinator PLKB berubah menjadi Pengawas PLKB.

Pelaksanaan Keluarga Berencana secara Nasional semakin berkembang dimana pada era reformasi terjadi suatu perubahan kebijakan Gerakan KB Nasional kembali menjadi Program KB Nasional, sesuai dengan Visi dan Misi yang baru. Demikian pula kelembagaan/organisasi BKKBN ikut mengalami penyempurnaan berdasarkan Kepres 166 Tahun 2000. Zaman semakin berubah, dimensi Program KB-pun ikut berubah. Tercatat pada akhir tahun 2003 Kelembagaan serta program KB tingkat Kab./Kota diserahkan kepada pemerintahan daerah, yang ditandai dengan Penyerahan P3D dari Pemerintah Pusat ke Pemerintahan Daerah, dan itu berarti seluruh tanggung jawab pelaksanaan Program KB ada di tangan pemerintahan Kabupaten/Kota.

Termasuk pengelolaan dan pembinaan PNS yang ada. Sejalan dengan 
perkembangan program kependudukan, Keluarga Berencana dan Pembangunan Keluarga yang terbaru berdasarkan UndangUndang Nomor 23 Tahun 2014 dan dikuatkan dengan Surat Edaran Menteri Dalam Negeri Nomor 18 tahun 2016 tentang Pemerintahan Daerah yang mengamanatkan adanya Dinas Pengendalian Penduduk dan KB, baik di tingkat provinsi maupun di kabupaten/kota yang terbagi dalam beberapa tipologi yaitu Tipe A, B dan C. Hal ini ditentukan berdasarkan kriteria umum dan kriteria khusus yang dimiliki masingmasing provinsi atau kabupaten/ kota. Kelembagaan BKKBN saat ini diharapkan dapat memperkuat peran strategis menjalankan program Kependudukan, Keluarga Berencana dan Pembangunan Keluarga sehingga menindaklanjuti hal tersebut dikeluarkan Peraturan Kepala Badan Kependudukan dan Keluarga Berencana Nasional No. 163 Tahun 2016 tentang Pedoman Nomenklatur, Tugas dan Fungsi Dinas Pengendalian Penduduk dan Keluarga Berencana di Provinsi, Kabupaten dan Kota bahwa perangkat daerah yang menyelenggarakan urusan pemerintahan bidang pengendalian penduduk dan keluarga berencana nomenklaturnya adalah Dinas Pengendalian Penduduk dan Keluarga Berencana.

Sedangkan ketentuan mengenai kedudukan, struktur organisasi, tugas dan fungsi serta tata kerjanya selanjutnya ditetapkan dengan Peraturan Kepala Daerah. Badan Kependudukan Keluarga Berencana Nasional Propinsi Sulawesi Tenggara bersama Kementrian Dalam Negeri, Sub Direktorat Pengendalian Penduduk dan Keluarga Berencana dan Biro Hukum Organisasi dan Humas BKKBN telah melakukan sosialisasi dan fasilitasi pembentukan kelembagaan program kependudukan dan keluarga berencana di Kabupaten dan Kota se-Sulawesi Tenggara dan dilaporkan di akhir Desember tahun 2016 ini seluruh Kabupaten Kota se Sulawesi Tenggara telah menyelsaikan Ranperda tersebut. Nomenklatur kelembagaan dan tenaga pengelola program KKBPK dapat diuraikan pada tabel 1. 
Tabel 1.

\section{Kelembagaan Organisasi Perangkat Daerah (OPD)-KB Kabupaten/Kota se Provinsi Sulawesi Tenggara Tahun 2016}

\begin{tabular}{|c|c|c|c|c|c|}
\hline \multirow[t]{2}{*}{ No } & \multirow{2}{*}{$\begin{array}{l}\text { Wilayah } \\
\text { Prov \& } \\
\text { Kab/Kota }\end{array}$} & \multicolumn{3}{|c|}{ PERDA / PERWALI } & \multirow[t]{2}{*}{ Kepala OPD-KB } \\
\hline & & Nomor & NOMENKLATUR & Type & \\
\hline 1 & Kab.Kolaka & $\begin{array}{l}5 \text { Tahun } 2016( \\
21 / 10 / 16)\end{array}$ & $\begin{array}{c}\text { Dinas Pengendalian Penduduk } \\
\text { dan KB }\end{array}$ & B & $\begin{array}{l}\text { dr. Hj. Muliati } \\
\text { Habibullah, M.Si }\end{array}$ \\
\hline 2 & Kab.Konawe & $\begin{array}{l}6 \text { Tahun } 2016 \\
(5 / 12 / 2016) \\
\end{array}$ & $\begin{array}{c}\text { Dinas Pengendalian Penduduk } \\
\text { dan KB }\end{array}$ & A & $\begin{array}{c}\text { Dra. Hj. Asriani Porosi, } \\
\text { M.Si }\end{array}$ \\
\hline 3 & Kab.Muna & $\begin{array}{l}6 \text { Tahun } 2016 \\
(5 / 11 / 2016) \\
\end{array}$ & $\begin{array}{c}\text { Dinas Pengendalian Penduduk } \\
\text { dan KB } \\
\end{array}$ & B & Drs. Muh Safei, M.Si \\
\hline \multirow{2}{*}{ No } & \multirow{2}{*}{$\begin{array}{c}\text { Wilayah } \\
\text { Prov \& } \\
\text { Kab/Kota }\end{array}$} & \multicolumn{3}{|c|}{ PERDA / PERWALI } & \multirow{2}{*}{ Kepala OPD-KB } \\
\hline & & Nomor & NOMENKLATUR & Type & \\
\hline 4 & Kab.Buton & $\begin{array}{l}5 \text { Tahun } 2016( \\
21 / 10 / 16)\end{array}$ & $\begin{array}{c}\text { Dinas Pengendalian Penduduk } \\
\text { dan KB }\end{array}$ & B & Nasbah, SE \\
\hline 5 & Kota Kendari & $\begin{array}{l}5 \text { Tahun } 2016 \\
(17 / 10 / 2016)\end{array}$ & $\begin{array}{l}\text { Dinas Pengendalian Penduduk } \\
\text { dan KB }\end{array}$ & B & Drs. Boy Azis \\
\hline 6 & Kota Bau-Bau & $\begin{array}{l}5 \text { Tahun } 2016 \\
(5 / 12 / 2016)\end{array}$ & $\begin{array}{c}\text { Dinas Pengendalian Penduduk } \\
\text { dan KB }\end{array}$ & B & Drs. Sudarman., M.Si \\
\hline 7 & $\begin{array}{l}\text { Kab.Konawe } \\
\text { Selatan }\end{array}$ & $\begin{array}{l}8 \text { Tahun } 2016 \\
(12 / 10 / 2016)\end{array}$ & $\begin{array}{l}\text { Dinas Pengendalian Penduduk } \\
\text { dan KB }\end{array}$ & B & Najib, S.Sos \\
\hline 8 & $\begin{array}{l}\text { Kab.Kolaka } \\
\text { Utara }\end{array}$ & $\begin{array}{l}3 \text { Tahun } 2016 \\
(15 / 9 / 2016)\end{array}$ & $\begin{array}{c}\text { Dinas Pengendalian Penduduk } \\
\text { dan KB }\end{array}$ & B & Saimah, SH \\
\hline 9 & Kab.Wakatobi & $\begin{array}{l}5 \text { Tahun } 2016 \\
(17 / 11 / 2016)\end{array}$ & $\begin{array}{l}\text { Dinas Pengendalian Penduduk } \\
\text { dan KB }\end{array}$ & A & Drs. Syafiuddin, M.Si \\
\hline 10 & Kab.Bombana & $\begin{array}{l}3 \text { Tahun } 2016 \\
(24 / 11 / 2016)\end{array}$ & $\begin{array}{l}\text { Dinas Pengendalian Penduduk } \\
\text { dan KB }\end{array}$ & B & Drs. A z i s., M.Si \\
\hline 11 & $\begin{array}{l}\text { Kab.Konawe } \\
\text { Utara }\end{array}$ & $\begin{array}{l}9 \text { Tahun } 2016 \\
(4 / 10 / 2016)\end{array}$ & $\begin{array}{l}\text { Dinas Pengendalian Penduduk } \\
\text { dan KB }\end{array}$ & B & $\begin{array}{l}\text { Drs. H. M. Kasim } \\
\text { Pagala, M.Si }\end{array}$ \\
\hline 12 & $\begin{array}{l}\text { Kab.Buton } \\
\text { Utara }\end{array}$ & $\begin{array}{l}6 \text { Tahun } 2016 \\
(4 / 11 / 2016)\end{array}$ & $\begin{array}{c}\text { Dinas Pengendalian Penduduk } \\
\text { dan KB }\end{array}$ & $\mathrm{C}$ & Mansyur, S.Sos., M.Si \\
\hline 13 & $\begin{array}{l}\text { Kab. Kolaka } \\
\text { Timur }\end{array}$ & $\begin{array}{l}21 \text { Tahun } 2016 \\
(21 / 11 / 2016)\end{array}$ & $\begin{array}{c}\text { Dinas Pengendalian Penduduk } \\
\text { dan KB }\end{array}$ & B & Nasruddin, SE., M.Si \\
\hline 14 & $\begin{array}{l}\text { Kab. Konawe } \\
\text { Kepulauan }\end{array}$ & 2 Tahun 2016 & $\begin{array}{l}\text { Dinas Pengendalian Penduduk, } \\
\text { KB, PP dan PA }\end{array}$ & $\mathrm{C}$ & $\begin{array}{l}\text { Dra. Hj. Sitti } \\
\text { Muhariah., M.S }\end{array}$ \\
\hline 15 & $\begin{array}{l}\text { Kab. Muna } \\
\text { Barat }\end{array}$ & $\begin{array}{l}1 \text { Tahun } 2016 \\
(7 / 10 / 2016)\end{array}$ & $\begin{array}{c}\text { Dinas Pengendalian Penduduk, } \\
\text { KB, PP dan PA }\end{array}$ & $\mathrm{C}$ & $\begin{array}{l}\text { La Ode Muhlisi, A.Kep, } \\
\text { M.Kes }\end{array}$ \\
\hline 16 & $\begin{array}{l}\text { Kab. Buton } \\
\text { Tengah }\end{array}$ & $\begin{array}{l}12 \text { Tahun } 2016 \\
(11 / 11 / 2016)\end{array}$ & $\begin{array}{l}\text { Dinas Pengendalian Penduduk } \\
\text { dan KB }\end{array}$ & B & Drs. Syamsuddin, M \\
\hline 17 & $\begin{array}{l}\text { Kab. Buton } \\
\text { Selatan }\end{array}$ & $\begin{array}{l}2 \text { Tahun } 2016 \\
(28 / 10 / 2016)\end{array}$ & $\begin{array}{c}\text { Dinas Pengendalian Penduduk } \\
\text { dan KB }\end{array}$ & B & La Asari, SP., M.Si \\
\hline
\end{tabular}

Sumber : Data Kepegawaian BKKBN Prov. Sultra 2016 
Tabel 2.

Jumlah Tenaga Pelaksana dan Pengelola Program Menurut Kabupaten/Kota di Provinsi Sulawesi Tenggara Tahun 2016

\begin{tabular}{|c|l|c|c|c|c|c|}
\hline \multirow{2}{*}{ No. Kab./Kota } & \multirow{2}{*}{2} & \multicolumn{3}{|c|}{ Tenaga Pelaksana dan Pengola Program } & Jumlah \\
\cline { 3 - 6 } & & Dokter & Bidan & PPLKB & PKB/PLKB & (5+6) \\
\hline 1 & & 3 & 4 & 5 & 6 & 7 \\
\hline 1 & Kolaka & 28 & 120 & 7 & 23 & 30 \\
\hline 2 & Konawe & 57 & 294 & 22 & 56 & 78 \\
\hline 3 & Muna & 11 & 60 & 0 & 14 & 14 \\
\hline 4 & Buton & 20 & 107 & 0 & 10 & 10 \\
\hline 5 & Kota Kdi & 26 & 189 & 10 & 20 & 30 \\
\hline 6 & Kota Bau-Bau & 26 & 109 & 0 & 10 & 10 \\
\hline 7 & Konsel & 30 & 299 & 20 & 22 & 42 \\
\hline 8 & Kolut & 14 & 187 & 0 & 56 & 56 \\
\hline 9 & Wakatobi & 22 & 125 & 8 & 20 & 28 \\
\hline 10 & Bombana & 37 & 165 & 22 & 73 & 95 \\
\hline 11 & Konut & 16 & 78 & 3 & 2 & 5 \\
\hline 12 & Butur & 11 & 144 & 6 & 2 & 8 \\
\hline 13 & Kolaka Timur & 9 & 50 & 12 & 12 & 24 \\
\hline 14 & Konawe Kepulauan & 8 & 65 & 0 & 38 & 38 \\
\hline 15 & Muna Barat & 8 & 30 & 0 & 2 & 2 \\
\hline 16 & Buton Tengah & 7 & 86 & 0 & 7 & 7 \\
\hline 17 & Buton Selatan & 2 & 74 & 7 & 1 & 8 \\
\hline & Sultra & 306 & 1.119 & 117 & 368 & 485 \\
\hline
\end{tabular}

Sumber : Data Kepegawaian BKKBN Prov. Sultra 2016

Keterangan:

1. Ratio PKB/PLKB (368) terhadap jumlah Desa (2.248) adalah 1: 5; yang berarti 1 PKB/PLKB membina sekitar 5 Desa/Kelurahan.

2. Ratio PPLKB/KUPT (117) terhadap jumlah Kecamatan 212 adalah $1: 2$ yang berarti 1 PPLKB/UPT membina sekitar 2 Kecamatan.
Berbagai keberhasilan yang di capai dalam pelaksanaan Program KB Nasional sampai di lini lapangan tidak terlepas dari dukungan dan peran serta Institusi Masyarakat Pedesaan seperti PPKBD dan Sub PPKBD. PPKBD di Sulawesi Tenggara dibentuk sejak tahun 1983/1984 dan Sub PPKBD pada tahun 1986/1987. Perkembangan institusi ini cukup menggembirakan baik dalam jumlah maupun perannya. Jumlah PPKBD dan Sub PPKBD sesuai data pada tabel 3. 
Tabel 3.

Jumlah PPKBD dan Sub PPKBD Menurut Kabupaten /Kota di Provinsi Sulawesi Tenggara Tahun 2016

\begin{tabular}{|c|c|c|c|}
\hline No & Kab/Kota & PPKBD & Sub PPKBD \\
\hline 1 & Kolaka & 135 & 445 \\
\hline 2 & Konawe & 361 & 1.108 \\
\hline 3 & Muna & 151 & 334 \\
\hline 4 & Buton & 95 & 285 \\
\hline 5 & Kota Kendari & 64 & 349 \\
\hline 6 & Kota Bau-Bau & 43 & 180 \\
\hline 7 & Konawe Selatan & 361 & 1.341 \\
\hline 8 & Kolaka Utara & 133 & 519 \\
\hline 9 & Wakatobi & 100 & 274 \\
\hline 10 & Bombana & 139 & 443 \\
\hline 11 & Konawe Utara & 146 & 442 \\
\hline 12 & Buton Utara & 90 & 250 \\
\hline 13 & Kolaka Timur & 133 & 502 \\
\hline 14 & Konawe Kepulauan & 96 & 292 \\
\hline 15 & Muna Barat & 86 & 193 \\
\hline 16 & Buton Tengah & 77 & 303 \\
\hline 17 & Buton Selatan & 70 & 262 \\
\hline & Total & 2.280 & 7.522 \\
\hline
\end{tabular}

Sumber : Data Kepegawaian BKKBN Prov. Sultra 2016

Keterangan:

1. Ratio PPKBD (2.280) terhadap jumlah PUS (455.758) adalah 1 : 200; Rasio Sub PPKBD (terhadap PUS adalah 1 : 61)

2. Ratio PPKBD terhadap PA (271.487) adalah 1 : 128; Sub PPKBD terhadap PA adalah $1: 41$
2. Pengaruh

Komunikasi

Interpersonal Terhadap Kinerja Penyuluh Keluarga Berencana (PKB)

Penelitian ini dilakukan di BKKBN Propinsi Sulawesi Tenggara. Dalam penelitian ini terdapat 40 sampel/responden Penyuluh Keluarga Berencana PNS secara keseluruhan yang terdiri dari 17 Kabupaten / Kota di Sulawesi Tenggara. Hingga akhir penelitian ini dilakukan, responden yang 
mengembalikan angket penelitian adalah 40 orang atau 100 persen dengan mengisi angket secara lengkap. Dengan demikian, secara metodologis dikatakan layak untuk dilakukan pengujian dan pembahasan hasil penelitian.

\section{a. Komunikasi Interpersonal (X1)}

Mulyana (2005) menyatakan "komunikasi antar pribadi (interpersonal communication) adalah komunikasi antara orang-orang secara tatap muka, yang memungkinkan setiap pesertanya menangkap reaksi orang lain secara langsung, baik secara verbal ataupun nonverbal". Komunikasi interpersonal dalam penelitian ini 4 indikator dan 10 item pertanyaan yang meliputi: keterbukaan (openess), empati (emphaty), dukungan (supportiveness) dan rasa positif (positiveness). Rekapitulasi jawaban responden terhadap komunikasi interpersonal dapat diuraikan sebagai berikut:

Tabel 4.

Deskripsi Jawaban Terhadap Variabel Komunikasi Interpersonal (X1)

\begin{tabular}{|c|c|c|c|c|c|c|c|c|c|c|c|c|c|}
\hline \multirow{2}{*}{$\begin{array}{l}\text { Indikator } \\
\text { variabel }\end{array}$} & \multirow{3}{*}{$\begin{array}{l}\text { Item } \\
\text { Butir }\end{array}$} & \multicolumn{10}{|c|}{ Frekuensi (f) dan Persentase (\%) Jawaban Responden } & \multirow{3}{*}{$\begin{array}{l}\text { Rerata } \\
\text { (Mean) }\end{array}$} & \\
\hline & & \multicolumn{2}{|c|}{ STS (1) } & \multicolumn{2}{|c|}{ TS (2) } & \multicolumn{2}{|c|}{$\mathrm{N}(3)$} & \multicolumn{2}{|c|}{ S (4) } & \multicolumn{2}{|c|}{ SS (5) } & & \\
\hline \multirow{4}{*}{$\begin{array}{c}\text { Keterbukaan } \\
\text { (X1.1) }\end{array}$} & & $\mathrm{F}$ & $\%$ & f & $\%$ & $\mathrm{f}$ & $\%$ & $\mathrm{f}$ & $\%$ & $\mathrm{f}$ & $\%$ & & \\
\hline & $\mathrm{X} 1.1 .1$ & 0 & 0,00 & 0 & 0,00 & 1 & 2,5 & 15 & 37,5 & 24 & 60,0 & 4,58 & \multirow{3}{*}{4,64} \\
\hline & $\mathrm{X} 1.1 .2$ & 0 & 0,00 & 0 & 0,00 & 1 & 2,5 & 12 & 30,0 & 27 & 67,5 & 4,65 & \\
\hline & $\mathrm{X} 1.1 .3$ & 0 & 0,00 & 0 & 0,00 & 1 & 2,5 & 10 & 25,0 & 29 & 72,5 & 4,70 & \\
\hline \multirow{3}{*}{ Empati (X1.2) } & $\mathrm{X} 1.2 .1$ & 0 & 0,00 & 0 & 0,00 & 2 & 5,0 & 15 & 37,5 & 23 & 57,5 & 4,52 & \multirow{3}{*}{4,63} \\
\hline & $\mathrm{X} 1.2 .2$ & 0 & 0,00 & 0 & 0,00 & 1 & 2,5 & 10 & 25,0 & 29 & 72,5 & 4,70 & \\
\hline & $\mathrm{X} 1.2 .3$ & 0 & 0,00 & 0 & 0,00 & 0 & 0,0 & 13 & 32,5 & 27 & 67,5 & 4,68 & \\
\hline \multirow{3}{*}{$\begin{array}{l}\text { Dukungan } \\
\text { (X1.3) }\end{array}$} & $\mathrm{X} 1.3 .1$ & 0 & 0,00 & 0 & 0,00 & 2 & 5,0 & 11 & 27,5 & 27 & 67,5 & 4,62 & \multirow{3}{*}{4,60} \\
\hline & $\mathrm{X} 1.3 .2$ & 0 & 0,00 & 0 & 0,00 & 0 & 0,0 & 18 & 45,0 & 22 & 55,0 & 4,55 & \\
\hline & $\mathrm{X} 1.3 .3$ & 0 & 0,00 & 0 & 0,00 & 1 & 2,5 & 13 & 32,5 & 26 & 65,0 & 4,62 & \\
\hline $\begin{array}{l}\text { Rasa Positif } \\
\text { (X1.4) }\end{array}$ & $\mathrm{X} 1.4 .1$ & 0 & 0,00 & 0 & 0,00 & 2 & 5,0 & 17 & 42,5 & 21 & 52,5 & 4,48 & 4,48 \\
\hline & \multicolumn{11}{|c|}{ Rerata Variabel Komunikasi Interpersonal (X1) } & \multicolumn{2}{|c|}{4,59} \\
\hline
\end{tabular}

Sumber: Data Primer (kuisioner) diolah, tahun 2020

Berdasarkan rekapitulasi jawaban responden atas variabel komunikasi interpersonal pada BKKBN Propinsi Sulawesi Tenggara seperti yang disajikan pada Tabel 4, menunjukkan bahwa deskripsi jawaban responden secara keseluruhan tentang komunikasi interpersonal menyatakan sudah sangat baik dengan nilai rerata 4,59. Artinya bahwa mayoritas responden menyatakan secara keseluruhan mengenai penerapan komunikasi interpersonal meliputi: keterbukaan, empati, dukungan dan rasa positif sudah sangat baik. 


\section{b. Kinerja Pegawai}

Kinerja adalah penilaian pegawai BKKBN Propinsi Sulawesi Tenggara atas hasil akhir dari aktivitas kerja yang dapat diukur melalui kemampuan kerja, kecakapan, keahlian dan sikap seorang pegawai dalam melaksanakan tugas. Kinerja diukur dengan 5 item pertanyaan yang terdiri dari kuantitas kerja, kualitas kerja, ketangguhan, kerja sama dan ketepatan waktu. Rekapitulasi jawaban responden terhadap kinerja diuraikan sebagai berikut:

Tabel 5.

Deskripsi Jawaban Terhadap Variabel Kinerja Pegawai (Y)

\begin{tabular}{|c|c|c|c|c|c|c|c|c|c|c|c|c|}
\hline \multirow{2}{*}{$\begin{array}{l}\text { Indikator } \\
\text { variabel }\end{array}$} & \multirow{2}{*}{$\begin{array}{l}\text { Item } \\
\text { Butir }\end{array}$} & \multicolumn{10}{|c|}{ Frekuensi (f) dan Persentase (\%) Jawaban Responden } & \multirow{3}{*}{ Rerata (Mean) } \\
\hline & & \multicolumn{2}{|c|}{ STS (1) } & \multicolumn{2}{|c|}{ TS (2) } & \multicolumn{2}{|c|}{$\mathrm{N}(3)$} & \multicolumn{2}{|c|}{$\mathrm{S}(4)$} & \multicolumn{2}{|c|}{ SS (5) } & \\
\hline \multirow{6}{*}{ Kinerja $(\mathrm{Y})$} & & $\mathrm{f}$ & $\%$ & $\mathrm{f}$ & $\%$ & $\mathrm{f}$ & $\%$ & $\mathrm{~F}$ & $\%$ & $\mathrm{f}$ & $\%$ & \\
\hline & Y1.1 & 0 & 0,00 & 0 & 0,00 & 1 & 2,5 & 26 & 65,0 & 13 & 32,5 & 4,30 \\
\hline & Y1.2 & 0 & 0,00 & 1 & 2,50 & 7 & 17,5 & 18 & 45,0 & 14 & 35,0 & 4,12 \\
\hline & $\begin{array}{l}1.3 \\
\end{array}$ & 0 & 0,00 & 0 & 0,00 & 22 & 55,0 & 15 & 37,5 & 3 & 7,5 & 3,52 \\
\hline & Y1.4 & 0 & 0,00 & 0 & 0,00 & 8 & 20,0 & 32 & 80,0 & 0 & 0,00 & 3,80 \\
\hline & Y1.5 & 0 & 0,00 & 0 & 0,00 & 7 & 17,5 & 28 & 70,0 & 5 & 12,5 & 3,95 \\
\hline & \multicolumn{11}{|c|}{ Rerata Variabel Kinerja (Y) } & 3,94 \\
\hline
\end{tabular}

Sumber: data primer (kuisioner) diolah, tahun 2020

Berdasarkan rekapitulasi jawaban responden atas variabel kinerja pada BkkbN Propinsi Sulawesi Tenggara seperti yang disajikan pada Tabel 5, menunjukkan bahwa deskripsi jawaban responden secara keseluruhan tentang kinerja menyatakan sudah sangat baik dengan nilai rerata 3,94. Artinya bahwa mayoritas responden menyatakan secara keseluruhan mengenai penerapan kinerja meliputi: kuantitas kerja, kualitas kerja, ketangguhan, tanggung jawab dan ketepatan waktu sudah terlaksana dengan baik.
Metode Analisis data yang digunakan dalam penelitian ini adalah menggunakan teknik analisis regresi sederhana dengan menggunakan program Statistical Product and Service Solutions (SPSS) versi 24. Hasil analisis SPSS diperoleh uji determinan $\left(\mathrm{R}^{2}\right)$. Kemudian uji hipotesis melalui uji_t.

\section{a. Uji Signifikan Parsial (Uji_t)}

Uji parsial digunakan untuk mengetahui pengaruh masing- masing variabel independen terhadap variabel dependen (Ghazali, 2013), yaitu dengan membandingkan masing-masing nilai t_statistik dari regresi dengan t_tabel dalam

\section{Hasil Penelitian}


menolak atau menerima hipotesis. Kriteria tersebut sebagai berikut:

1. H0 diterima jika nilai probabilitas $($ signifikan $\mathrm{t})>0,05$ dan $p$ value $>$ 0,05

2. H0 ditolak jika nilai probabilitas (signifikan $\mathrm{t})<0,05$ dan $p$ value $<$ 0,05 .

Hasil perhitungan regresi sederhana dengan menggunakan aplikasi software SPSS 24 adalah sebagai berikut:

Tabel 6.

Hasil perhitungan Regresi sederhana

\begin{tabular}{|c|c|c|c|c|c|c|}
\hline \multirow{2}{*}{\multicolumn{2}{|c|}{ Model }} & \multicolumn{2}{|c|}{$\begin{array}{c}\text { Unstandardized } \\
\text { Coefficients }\end{array}$} & \multirow{2}{*}{$\begin{array}{c}\begin{array}{c}\text { Standardized } \\
\text { Coefficients }\end{array} \\
\text { Beta }\end{array}$} & \multirow[b]{2}{*}{$\mathrm{t}$} & \multirow[b]{2}{*}{ Sig. } \\
\hline & & B & $\begin{array}{l}\text { Std. } \\
\text { Error }\end{array}$ & & & \\
\hline \multirow[t]{2}{*}{1} & (Constant) & 2.510 & .665 & & 3.773 & .001 \\
\hline & $\mathrm{X} 1$ & .361 & .168 & .330 & 2.155 & .038 \\
\hline
\end{tabular}

a. dependent variabel: Y

\section{Sumber: Hasil Olahan Data SPPS 24, tahun 2020}

komunikasi interpersonal (X1) berpengaruh

Persamaan rumus regresi sederhana dapat diperoleh hasil sebagai berikut:

\section{$(\mathrm{Y})=\mathrm{W}_{1} \mathrm{X}_{1}+\mathrm{W}_{\mathbf{n}} \mathrm{X}_{\mathbf{n}}$$$
(\mathrm{Y})=0,330(\mathrm{X} 1)
$$ \\ (Hair et al., 2010: 4)}

Berdasarkan Tabel 6, menunjukkan bahwa nilai koefisien regresi variabel motivasi kerja $\left(b_{1}\right)$ bernilai positif, yaitu 0,330 artinya setiap peningkatan komunikasi interpersonal sebesar 1 satuan, maka akan meningkatkan kinerja sebesar 0,330 satuan dengan asumsi variabel independen lain nilainya tetap. Kemudian hasil penelitian ini menunjukkan bahwa variabel komunikasi interpersonal berpengaruh positif dan signifikan terhadap kinerja. Hal ini dapat dijelaskan sebagai berikut: Variabel positif dan signifikan terhadap kinerja pegawai, hal ini dibuktikan dengan nilai t_hitung > t_tabel atau 2,155 > 1,683 dan nilai signifikan sebesar 0,380 lebih kecil dari $\alpha=0,05$ atau $5 \%$.

\section{b. Uji Koefisien Determinasi $\left(\mathbf{R}^{\mathbf{2}}\right)$}

Pada model regresi sederhana, koefisien determinasi $\left(\mathrm{R}^{2}\right)$ digunakan untuk mengukur tingkat kemampuan model dalam menerangkan variasi pada variabel dependen (Ghazali, 2011). Nilai $R^{2}$ yang mendekati nol diartikan variabel independen dalam menjelaskan variabel dependen terbatas, sebaliknya jika nilai $\mathrm{R}^{2}$ mendekati satu berarti variabel independen memberikan hampir semua informasi yang 
diperlukan untuk memprediksi variabel dependen (Ghazali, 2011).

Tabel 7.

PengujianKoefisien Determinasi $\left(R^{2}\right)$ Model Summary

\begin{tabular}{|l|r|r|r|c|}
\hline Model & $\mathrm{R}$ & R Square & $\begin{array}{c}\text { Adjusted } \\
\text { R Square }\end{array}$ & $\begin{array}{c}\text { Std. } \\
\text { Error of } \\
\text { the } \\
\text { Estimate }\end{array}$ \\
\hline 1 & $.330^{\mathrm{a}}$ & .109 & .085 & .31591 \\
\hline
\end{tabular}

a. Predictor: (Constant),X1

b. Dependent Variable:Y

\section{Sumber: Hasil Olahan Data SPPS 24, tahun 2020}

Berdasarkan Tabel 7, menunjukkan bahwa nilai $\mathrm{R}^{2}$ adalah 0,330 mengindikasikan bahwa variabel kinerja pegawai (Y) mampu dijelaskan oleh variabel independen berupa komunikasi interpersonal (X1) atau nilainya sebesar 33,0 persen dan sisanya 67 persen dijelaskan oleh variabel lain diluar model penelitian ini.

\section{Pengaruh}

Komunikasi

\section{Interpersonal terhadap Kinerja Pegawai}

Komunikasi interpersonal

berpengaruh positif dan signifikan terhadap kinerja pegawai yang dilakukan oleh penyuluh lapangan keluarga berencana BKKBN propinsi Sulawesi tenggara. Hal ini dibuktikan dengan jawaban responden secara keseluruhan tentang komunikasi interpersonal menyatakan sudah sangat baik dengan nilai rata-rata 4,59. Artinya bahwa mayoritas responden menyatakan secara keseluruhan

mengenai

penerapan

komunikasi interpersonal meliputi:

keterbukaan, empati, dukungan dan rasa positif sudah sangat baik. Kemudian berdasarkan hasil uji parsial analisis regresi komunikasi interpersonal (X1) berpengaruh signifikan terhadap kinerja pegawai. Hal ini sesuai dengan kondisi di lapangan menunjukkan bahwa komunikasi dinilai sebagai aspek yang penting ketika melakukan penyuluhan, komunikasi adalah proses penyampaian pesan yang dilakukan oleh komunikator kepada komunikan.

Orang yang memberi pesan (komunikator) dalam hal ini adalah Penyuluh Keluarga Berencana (PKB) Sulawesi tenggara dan yang menerima pesan (komunikan) adalah masyarakat. Dalam praktiknya PKB Sulawesi tenggara melakukan sosialisasi program KB menggunakan beberapa metode, contohnya: sosialisasi seperti penyuluhan, konseling dan 
kunjungan ke rumah masyarakat atau door to door. Komunikasi menjadi sebuah modal awal yang sangat penting dalam sebuah sosialisasi mengenai program Penyuluh Keluarga Berencana (PKB) kepada masyarakat.

Komunikasi interpersonal merupakan suatu proses komunikasi yang paling efektif, Karena para penyuluh komunikasi dapat terus menerus saling menyesuaikan diri. Dengan adanya hubungan komunikasi interpersonal maka hubungan yang terjalin akan semakin harmonis dikarenakan adanya sikap saling memahami, sehingga akan memunculkan rasa nyaman dan mampu meningkatkan kinerja. Temuan ini sesuai dengan teori yang yang diungkapkan oleh Efendi (2006) mendifinisikan komunikasi sebagai proses penyampaian pesan oleh seseorang kepada orang lain untuk memberitahu, mengubah sikap, pendapat, atau perilaku, baik secara lisan (langsung) ataupun tidak langsung (melalui media). Sopiah (2008) komunikasi didefinisikan sebagai penyampaian atau pertukaran informasi dari pengirim kepada penerima baik secara lisan, tertulis, maupun menggunakan alat komunikasi. Baharum et al (2005) mendefinisikan bahwa komunikasi adalah aspek dan elemen yang penting dalam kefungsian sebuah organisasi.
Carl I. Hovland (Effendy, 2006) mendefinisikan bahwa komunikasi adalah proses yang memungkinkan seseorang (komunikator) menyampaikan rangsangan untuk mengubah perilaku orang lain (komunikan). Burns dan Kelly (Wexley dan Yulk, 2005) mendifinisikan bahwa komunikasi sebagai penyampaian informasi antara dua orang atau lebih. Komunikasi dapat juga meliputi pertukaran informasi antara manusia dan mesin. Komunikasi merupakan suatu proses yang vital dalam organisasi karena komunikasi diperlukan bagi efektivitas kepemimpinan, perencanaan, pengendalian, koordinasi, latihan, manajemen konflik, serta prosesproses organisasi lainnya. Hal ini sesuai dengan variabel penelitian komunikasi interpersonal berpengaruh positif dan signifikan yang dilakukan oleh, Festus Femin, (2014), Wawan Ridwan, Soewarto Hardhienata dan M. Entang (2016) dan Saftian Pradana, I Wayan Bagia dan Gede Putu Agus Jana Susila (2016), Abdul Ghofar et al (2018), Saraih U. N. et al (2019), Nana Herdiana Abdurrahman (2018) dan Syifa Aulia Gumay et al (2018). 


\section{Kesimpulan}

Berdasarkan pengujian hipotesis, hasil pembahasan dan temuan penelitian, dapat dikemukakan beberapa kesimpulan bahwa hubungan komunikasi interpersonal yang terdiri dari keterbukaan, empati, dukungan dan rasa positif ditingkatkan maka meningkatkan kinerja penyuluh. Artinya bahwa komunikasi yang baik antara penyuluh dan masyarakat akan mampu memperoleh dan mengembangkan tugas yang diembannya, sehingga kinerja menjadi semakin baik. Sebaliknya, apabila terjadi komunikasi yang buruk akibat tidak terjalinnya hubungan yang baik, maka akan terjadi sikap acuh tak acuh dan perbedaan pendapat atau konflik yang berkepanjagan dan sebgainya, sehingga akan berdampak pada hasil kinerja yang tidak maksimal.

\section{Daftar Pustaka}

Abdullah, M. 2014. Manajemen dan Evaluasi Kinerja Karyawan. Yogyakarta : Penerbit Aswaja Pressindo.

Abdul Ghofar et al (2018). The Effect of Interpersonal Communication, SelfEngagement and Organizational Commitment Toward The Employee Performance.

Abriyoso, J. O. dkk (2012). Hubungan Efektivitas Komunikasi Antarpribadi dalam Keluarga dengan Motivasi Belajar Anak di Sekolah.

Agus M. Hardjana. (2003). Komunikasi intrapersonal \& Komunikasi
Intrpersonal. Yogyakarta: Penerbit Kanisius.

Amstrong, dan Kotler 2003, Dasar-dasar Pemasaran, Jilid 1, Edisi Kesembilan, Penerbit PT. Indeks Gramedia, Jakarta

Anwar Prabu Mangkunegara. (2007). Manajemen Sumber Daya Manusia Perusahaan. Bandung: PT. Remaja Rosdakarya.

Anwar Prabu Mangkunegara. 2009. Evaluasi Kinerja Sumber Daya Manusia. Bandung: Penerbit Refika Aditama.

Arni, Muhammad. 2005. Komunikasi Organisasi. Jakarta. Bumi Aksara

Arikunto, S. 2002. Metodologi Penelitian Suatu Pendekatan Proposal. Jakarta: PT. Rineka Cipta.

Arikunto, Suharsimi. (2012). Prosedur Penelitian Suatu Pendekatan Praktek. Jakarta: Rineka Cipta

Z, Mulyana. 2010. Rahasia Menjadi Guru Hebat. Jakarta: Grasindo.

AW Suranto. (2011). Komunikasi Interpersonal. Yogyakarta: Grha Ilmu.

Bangun, Wilson. 2012. "Manajemen Sumber Daya Manusia". Jakarta: Erlangga.

Bill Foster dan Karen R. Seeker, 2001 "Pembinaan Untuk Meningkatkan Kinerja Karyawan" penerbit: PT.Toko Gunung Agung Tbk Jakarta,

Buhrmester, Duane. 1996. Intimacy of Friendship, Interpersonal Competence, and Adjustment During Preadolescence and Adolescence. Child Development, 61, 1101-1111.

Bernardin and Russel, 1993. Human Resource Management. New Jersey: International Editions Upper Saddle River, Prentice Hall.

Bienvenu, M.J, (1987). Interpersonal Communication Inventory. University Associates. In.

Cangara, Hafied. 2010. Pengantar Ilmu Komunikasi. Jakarta : Rajawali Pers

Cooper, Donald R. and Pemela S. Schindler. (2003). Business Research Methods, 
International Edition, McGraw-Hill Companies, Inc. New York.

David, H. dan Wheelen. 2004. "Manajemen Strategis: Konsep. Edisi ketujuh". PT. Prenhallindo, Jakarta.

Enjang, AS. 2009. Komunikasi Konseling. Bandung: Nuansa.

Effendy Onong Uchana, 2003. Ilmu Teori dan Filsafat Komunikasi, Bandung, PT Citra Aditya Bakti.

Festus Femin, 2014. The Impact of Communication on Workers' Performance in Selected Organisations in Lagos State, Nigeri.

Flippo, Edwin B. 2002. Manajemen Personalia. Jakarta: Erlangga

Gibson, Charles H., 2001, Financial Reporting Analysis, 8thedition, SouthWestern College Publishing.

Gibson, Charles H, 2012. Financial Reporting Analysis. $8^{\text {th }}$ Edition, South Western College Publishing.

Hasibuan, Malayu S.P, 2001. Manajemen Sumber Daya Manusia, bumi askara: Jakarta.

Hasibuan, Malayu. 2002. Manajemen Sumber Daya Manusia . Bumi Aksara. Jakarta.

Hasibuan , Melayu, S.P, 2007. Manajemen Sumber Daya Manusia. Edisi Revisi. Bumi Aksara: Jakarta.

Hadari Nawawi. 2004. Manajemen Sumber Daya Manusia. Ghalia Indonesia.

Jakarta.

Handoko, T. Hani, 1992. Manajemen, Edisi 2. Yogyakarta: BPFE.

Handoko, T. Hani. 2002. Manajemen Personalia dan Sumber Daya Manusia. Yogyakarta : BPFE.

Kriyantono, Rahmat. 2007. Teknis Praktis Riset Komunikasi (Disertai contoh Praktis Riset Media, Public Relations, Advertising, Komunikasi Organisasi, Komunikasi Pemasaran). Jakarta : Kencana.

L. Mathis, Robert \& H. Jackson, John. 2011. Human Resource Management (edisi
10). Jakarta : Salemba Empat.

Marcy Rita et al (2019) Moderating effect of organizational citizenship behavior on the effect of organizational commitment, transformational leadership and work motivation on employee performance.

Mathis, Robert.L dan Jackson, John H, 2002. Manajemen Sumber Daya Manusia, Salemba Empat, Jakarta

Mathis, Robert L dan Jackson, John H, 2004. Manajemen Sumber Daya Manusia, Buku ke dua. Salemba Empat. Jakarta

Mathis, R.L. \& J.H. Jackson. 2006. Human Resource Management: Manajemen Sumber Daya Manusia. Terjemahan Dian Angelia. Jakarta: Salemba Empat.

Mulyana, Deddy, dan Jalaludin Rakhmat, 2005. Komunikasi Antar Budaya: Panduan Berkomunikasi dengan OrangOrang Berbeda Budaya. Bandung: PT.Remaja Rosdakarya.

Nana Herdiana Abdurrahman (2018) The effect of interpersonal communication skills and work motivation on performance of marketing employee.

Naresh K. Malhotra. 2010. Marketing Research. An Applied Orientation Sixth Edition Pearson Education.

Nazir, Moh. Ph. D. 2009. Metode Penelitian. Jakarta: Ghalia Indonesia

Nawawi, Hadari. 2008. Manajemen Sumber Daya Manusia Untuk Bisnis Yang Kompetitif. Yogyakarta : Gadjah Mada Univesity Press.

Onong Uchjana, Effendy. 2006. Ilmu Komunikasi; Teori dan Praktek. Bandung:

Penerbit Remaja Rosda Karya

Peraturan Pemerintah Republik Indonesia Nomor 46 tahun 2011 Tentang Penilaian Prestasi Kerja Pegawai Negeri Sipil, penilaian prestasi kerja

Rivai, Basri,Veithzal dan Sagala, E. J. 2005. Manajemen Sumber Daya Manusia 
untuk Perusahaan dari Teori ke Praktik. Jakarta : Penerbit Rajawali Pers.

Rummler, G. A., dan Brache A, P. (1995). Improving Performance: How To Manage the White Space on the Organization Chart. The Jossey-Bass Management Series. Jossey-Bass, Inc., 350 Sansome Street, San Francisco, CA 94104.

Robbins, Stephen P. 1996. Perilaku Organisasi.Edisi ke 7 (Jilid II). Jakarta : Prehallindo.

Robbins, P. Stephen. (2006). Perilaku Organisasi. Edisi Sepuluh. Diterjemahkan oleh: Drs. Benyamin Molan. Erlangga, Jakarta.

Robbins, S. 2008. Perilaku Organisasi, Jilid I dan II, alih Bahasa : Hadyana Pujaatmaja. Jakarta: Prenhallindo.

Robbins, S. (2012). Perilaku organisasi. Penerbit Salemba Empat. Jakarta.

Robbins, S. \& Coulter, M. (2012). Management. Eleventh edition. Prentice Hall. New Jersey.

Saftian Pradana, I Wayan Bagia dan Gede Putu Agus Jana Susila, 2016. Pengaruh Kompetensi Interpersonal dan Motivasi Kerja Terhadap Kinerja Pegawai.

Saraih U. N. et al (2019) Understanding The Effects Of Interpersonal Communication and Task Design On Job Performance Among Employees In The Manufacturing Company.

Simamora, Henry. 2006. Manajemen Sumberdaya Manusia. Yogyakarta: Sekolah Tinggi Ilmu Ekonomi YKPN.

Simanjuntak. 2005. Manajemen Dan Evaluasi Kinerja. Jakarta: Fakultas Ekonomi Universitas Indonesia.

Sugiyono, 2000. Metode Penelitian Bisnis. Cetakan Keduabelas, Alfabeta: Bandung.

Sugiyono. 2011. Metode Penelitian Kuantitatif, Kualitatif dan R\&D. Bandung: Afabeta.
Sutrisno, Edy. 2010. Manajemen Sumber Daya Manusia. Jakarta: Kencana.

J. Supranto. 2001. Pengukuran Tingkat Kepuasan Pelanggan Untuk Menaikkan Pangsa Pasar. Jakarta : Rineka Cipta.

J. Supranto. 2005. Pengukuran Tingkat Kepuasan Pelanggan Untuk Menaikkan Pangsa Pasar. Jakarta : Rineka Cipta.

Sedarmayanti.2009. Sumber Daya Manusia dan Produktivitas Kerja. Bandung: CV Mandar Maju.

Syifa Aulia Gumay dkk (2018) Komunikasi Interpersonal dan Lingkungan Kerja Terhadap Kinerja Karyawan PT. Euro Management Indonesia.

Wibowo, 2007. Manajemen Kinerja. PT. Raja Grafindo Parsada: Jakarta. 